\title{
ANALISIS BREAK EVEN POINT DAN RETURN OF INVESTMENT PADA USAHA IKAN ASIN DI KELURAHAN SUMBER JAYA KECAMATAN KAMPUNG MELAYU KOTA BENGKULU
}

\author{
${ }^{1}$ Rita Feni, ${ }^{2}$ Fithri Mufriantie, ${ }^{3}$ Ilham Saputra \\ ${ }^{1,2,3}$ Fakultas Pertanian Universitas Muhammadiyah Bengkulu \\ Email: ritafeniafif@gmail.com
}

\begin{abstract}
ABSTRAK
Penelitian ini bertujuan untuk mengetahui Break Event Point (BEP) dan Return Of Investment (ROI) pada usaha ikan asin di kelurahan sumber jaya kecamatan kampung melayu kota Bengkulu.

Lokasi penelitian i ditentukan dengan cara sengaja (porposive) mengingat lokasi tersebut merupakan salah satu sentra produksi ikan asin di kota Bengkulu yaitu di kelurahan Sumber Jaya kecamatan kampung melayu kota Bengkulu. Metode yang digunakan adalah metode sensus yaitu dengan mengambil seluruh anggota populasi sebagai responden.

Hasil penilitian menunjukkan bahwa usaha ikan asin dikelurahan sumber jaya kecamatan kampung melayu kota Bengkulu sudah melampauii BEP dengan keuntungan sebesar Rp. 1.378.797,-- per produksi. Nilai ROI usaha ikan asin di kelurahan Sumber Jaya kecamatan Kampung Melayu kota Bengkulu sebesar 2,21\%.
\end{abstract}

Kata kunci : Break Event Point, Return Of Investment (ROI), Ikan Asin.

\section{PENDAHULUAN}

Indonesia sebagai Negara maritim yang sngat kaya dengan kekayaan lautnya, pemerintahan saat ini giat mengembangkan industry di bidang kelautan. Keadaan ini tentunya sangat berpengaruh terhadap para pengusaha industry perikanan untuk lebih meningkatkan lagi usahanya dibidang perikanan. ( Warsidi, 2010 : 9).

Sektor kelautan dan perikanan merupakan salah satu sektor ekonomi yang memiliki peranan dalam pembangunan ekonomi nasional, khususnya dalam penyediaan bahan pangan protein, perolehan devisa dan penyediaan lapangan kerja.( Mulyadi S.2007 : 15).

Ikan Asin adalah ikan yang mendapatkan perlakuan tertentu menjadi bahan makananan dengan adanya campuran garam. Ikan sebagai bahan makanan yang mengandung protein tinggi dan mengandung asam amino esansial yang diperlukan oleh tubuh, disamping nilai biologisnya mencapai $90 \%$. Dengan jaringan ikatan sedikit sehingga mudah direncanakan. (Adawyah, Rabiatul, 2008).

Sebagaimana diketahui ikan merupakan produk yang sangat mudah mengalami pembusukan. Secara umum 
kerusakan atau pembusukan ikan dan hasil olahannya dapat digolongkan pada: 1) Kerusakan biologi, 2) Kerusakan enzimatis, 3) Kerusakan fisika, 4) Kerusakan kimiawi. Untuk menghindari pembusukan dilakukan berbagai cara salah satunya adalah melalui proses penggaraman. Selama proses penggaraman berlangsung terjadi penetrasi garam kedalam tubuh ikan dan keluarnya cairan dari tubuh ikan karena adanya perbedaan konsentarsi. Cairan tersebut dengan cepat akan melarutkan kristal garam atau pengenceran larutan garam. Bersamaan dengan keluarnya cairan dari tubuh ikan, partikelgaram pun masuk kedalam tubuh ikan. Ikan yang diolah dengan proses penggaraman ini dinamakan ikanasin (Adawyah, 2008).

Menurut sutrisno (2000) dalam Sutarni, dkk. (2014) untuk mengetahui tingkat BEP digunakan perhitungan BEP dengan pendekatan matematik dapat dilakukan dengan dua cara, yaitu (1) atas dasar unit dan (2) atas dasar rupiah. BEP merupakan metode untuk menganalisis kesalinghubungan antara biaya produksi, keuntungan, dan volume penjualan. Analisis ini didasarkan pada perilaku biaya dalam kaitanya dengan penerimaan penjualan.

Sedangkan menurut Soekartawi (2006), Return of Invesment (ROI) adalah keuntungan yang diperoleh dibagi dengan modal produksi dikali seratus persen atau persentase efesiensi penggunaan modal dari keuntungan yang didapat.

Kota Bengkulu terletak antara $3^{\circ} 45^{\prime}-3^{\circ} 59^{\prime}$ Lintang Selatan serta $102^{\circ}$ $14^{\text {‘ }}-102^{\circ} 22^{\prime}$ Bujur Timur. Berdasarkan posisi geografisnya, Kota Bengkulu di sebelah utara berbatsan dengan Kabupaten Bengkulu Tengah, di sebelah selatan berbatsan dengan Kabupaten Seluma, di sebelah timur berbatasan dengan Kabupaten Bengkulu Tengah dan di sebelah barat berbatsan dengan Samudra Indonesia (BPS Kota Bengkulu, 2018).

Kecamatan kampung melayu, lebih tepatnya di kelurahan sumber jaya merupakan salah satu daerah yang sebagian besar masyarakatnya bekerja sebagai pembuat ikan asin. Daerah tersebut di dekat pelabuhan pulai bai yang setiap harinya banyak nelayan yang menyediakan ikan segar untuk bahan baku pembuatan ikan asin. Usaha ikan asin di kelurahan sumber jaya sebagian besar dilakukan oleh nelayan tradisional dengan skala kecil atau usaha rumah tangga pada umumnya.

Dalam pelaksanaannya usaha ikan asin di kelurahan sumber jaya kecamatan kampung melayu kota Bengkulu memiliki resiko yaitu tidak adanya jaminan ketersediaan bahan baku ikan laut yang selalu ada, serta usaha pengolahan ikan 
asin yang sangat tergantung pada faktor alam berupa sinar matahari dan tidak tidak adanya perhitungan secara detail dengan setiap biaya-biaya, penerimaan dan keuntungan yang diperoleh dalam setiap produksi.

Berdasarkan hal tersebut diatas maka diperlukan suatu penelitian mengenai Analisis Break Even Point dan Return Of Invesmen (ROI) pada usaha ikan asin di Kelurahan Sumber Jaya Kecamatan Kampung Melayu Kota Bengkulu

\section{METODE PENELITIAN}

\section{MetodePenelitian}

Metode penelitian yang digunakan dalam penelitian ini adalah metode Sensus, yaitu dimana semua anggota populasi dijadikan sampel. (Sugiyono, 2014 : 68).

\section{Lokasi Penelitian}

Penelitian dilaksanakan di kelurahan Sumber Jaya kecamatan Kampung Melayu kota Bengkulu. Lokasi penelitian diambil secara sengaja (purposive) dengan pertimbangan daerah kelurahan sumber jaya kecamatan kampung melayu ini merupakan salah satu sentra lokasi pengolahan ikan asin di kota Bengkulu.

\section{Teknik Pengumpulan Data}

Teknik pengumpulan data yaitu secara primer dan sekunder.

1. Data primer
Data primer adalah data yang mengacu pada informasi yang diperoleh dari tangan pertama oleh peneliti yang berkaitan dengan variabel minat untuk tujuan spesifik studi. Data primer diperoleh dari yaitu :

1) Wawancara

Teknik ini digunakan guna unutuk mendapatkan data primer melalui wawancara langsung dengan responden berdasarkan daftar pertanyaan atau kuisioner yang telah dipersiapkan terlebih dahulu.

\section{2) Observasi}

Merupakan suatu metode di pakai untuk meneliti beberapa segi dari masalah yang dijadikan sasaran untuk memperoleh fakta-fakta yang diperlukan. Observasi dilakukan untuk memperoleh fakta-fakta berdasarkan pengamatan peneliti(Soekartawi, 2006: 26).

\section{Data Sekunder}

Data sekunder adalah sumber data yang tidak langsung memberikan data kepada pengumpul data/peneliti. Data sekunder ini sifatnya mendukung keperluan data primer seperti buku-buku, literature dan bacaan yang berkaitan dengan judul peneliti.

\section{Penentuan Responden}

Metode yang digunakan dalam penelitian ini yaitu menggunakan metode 
sensus, dimana seluruh anggota populasi yang berjumlah 28 orang dijadikan sebagai responden yaitu pengusaha pada usaha ikan asin skala rumah tanngga dikelurahan Sumber Jaya kecamatan Kampung Melayu kota Bengkulu.

\subsection{Analisa Data}

\section{Biaya produksi}

Menurut Mulyadi (2005), Biaya produksi mmerupakan biaya-biaya yang terjadi untuk mengolah bahan baku menjadi produk yang siap di jual. Menurut pengeluarannya, secara garis besar biaya produksi dibagi menjadi biaya bahan baku, biaya tenaga kerja dan biaya overhead pabrik.

Biaya produksi adalah semua pengeluaran yang digunakan, total biaya tetap dihitung dengan menggunakan rumus sebagai berikut guna untuk mengetahui keseluran biaya yang dikeluarkan selama proses produksi:

$$
\mathbf{T C}=\mathbf{F C}+\mathrm{VC}
$$

Dimana :

$$
\begin{aligned}
& \mathrm{TC}=\text { Total Biaya }(\mathrm{Rp}) \\
& \mathrm{FC}=\text { Biaya Tetap }(\mathrm{Rp}) \\
& \mathrm{VC}=\text { Biaya Variabel }(\mathrm{Rp})
\end{aligned}
$$

\section{Penerimaan Dan Keuntungan}

a. Penerimaan

Penerimaan usaha adalah perkalian antara produksi yang diperoleh dengan harga jual. (Soekartawi 2006 : 54)
Pernyatan ini dapat dituliskan sebagai berikut:

$$
\mathbf{T R}=\mathbf{P} \times \mathbf{Q}
$$

Keterangan:

$\mathrm{TR}=$ Jumlah Penerimaan (total revenue)

$\mathrm{P} \quad=$ Harga Jual

Q $\quad=$ Jumlah Produksi

b. Keuntungan

$$
\pi=\mathbf{T R}-\mathbf{T C}
$$

Keterangan:

$\Pi \quad=$ keuntungan (profit) $(\mathrm{Rp})$

$\mathrm{TR}=$ total penerimaan (total revenue) (Rp)

$\mathrm{TC}=$ Biaya total (total cost) $(\mathrm{Rp})$

\section{Break Even Point (BEP)}

Titik impas (break event point) adalah suatu analisis untuk menentukan dan mencari jumlah barang atau jasa yang harus dijual kepada konsumen pada harga tertentu untuk menutupi biaya yang timbul serta mendapatkan keuntungan atau dengan kata lain menguntungkan dan layak untuk diusahakan.

$$
\begin{aligned}
& \text { Menurut Sunyoto }(2013 \\
& \text { :123)analisis break even point adalah } \\
& \text { merupakan suatu teknik analisis yang } \\
& \text { ditunjukan untuk menghasilkan informasi } \\
& \text { dan dengan memusatkan perhatian pada } \\
& \text { penentuan suatu keadaan dimana volume } \\
& \text { kegiatan (yang diukur dengan hasil } \\
& \text { penjualan) tidak menghasilkan laba tetapi } \\
& \text { juga tidak mengalami kerugian. }
\end{aligned}
$$


Menurut Subur Harahap (2004) dalam https://www.maxmanroe.com. pengertian BEP adalah suatu kondisi perusahaan tidak memperoleh laba dan tidak menderita kerugian. Artinya semua biaya yang telah dikeluarkan untuk operasi produksi bisa ditutupi oleh pendapatan dari penjualan produk.

Break even point (BEP) terdiri dari beberapa komponen di dalamnya. Adapun komponen-komponen BEP adalah sebagai berikut :

\section{Biaya Tetap (Fixed Cost)}

Biaya tetap adalah biaya yang konstan jika perusahaan melakukan kegiatan produksi ataupun tidak melakukan produksi.

2. Biaya Variabel (Variabel Cost)

Biaya variabel adalah biaya per unit dimana sifatnya dinamis tergantung pada tindakan volume produksi. Jika produksi yang direncanakan meningkat maka biayaa variabelnya akan meningkat.

3. Harga Penjualan (Selling Price) Harga penjualan adalah harga jual yang ditetapkan per unit barang atau jasa yang telah diproduksi oleh perusahaan.

BEP akan tercapai apa bila kondisi total penerimaan sama dengan total biaya $(\mathrm{TR}=\mathrm{TC})$ pada saat ini keuntungan sama dengan nol.
Rumus (BEP) ada dua macam rumus yang dapat digunakan untuk Analisis Break EvenPoint yaitu :

1. BEP Dalam Unit

$$
\text { BEP = FC/ }(\text { P-VC) }
$$

Dimana :

FC = Fixed Cost (Biaya Tetap)

$\mathrm{P} \quad=$ Price Per Unit (Harga Per

Unit)

VC = Variabel Cost / Unit

2. BEP Dalam Rupiah

$$
\mathrm{BEP}=\mathrm{FC} /[\mathbf{1}-(\mathrm{VC} / \mathrm{S})]
$$

Keterangan :

$$
\begin{aligned}
& \mathrm{FC} \quad=\text { Fixed Cost (biaya tetap) } \\
& \mathrm{VC} \quad=\text { Variabel Cost } \\
& \mathrm{S} \quad=\text { Sales Volume (Volume } \\
& \text { Penjualan) }
\end{aligned}
$$

\section{Analisis ROI}

Menurut Soekartawi (2006), Return of Invesment (ROI) adalah keuntungan yang diperoleh dibagi dengan modal produksi dikali seratus persen atau persentase efesiensi penggunaan modal dari keuntungan yang didapat

ROI adalah keuntungan yang diperoleh dari jumlah modal. Nilai ini dapat digunakan intuk mengetahui efesiensi penggunaan modal. Nilai ini dapat mengetahui efesiensi penggunaan modal.

Adapun rumus ROI dalam rahardi,dkk (1999) adalah :

$$
R O I=\frac{\text { Laba usaha }}{\text { modal }} \times 100 \%
$$


Dimana : laba usaha adalah keuntungan yang di peroleh dari penerimaan dikurang dengan total biaya, dan modal yaitu modal seluruh infestasi yng dikeluarkan dalam usaha tersebut.

\section{Definisi Dan Operasional Variabel}

1. Responden adalah pelaku usaha pengolahan ikan asin di kelurahan sumber jaya kecamatan kampung melayu kota Bengkulu.

2. Ikan asin adalah ikan laut yang diawetkan di kelurahan sumber jaya kecamatan kampung melayu kota Bengkulu.

3. Biaya adalah jumlah biaya penguluaran yang dilakukan pada usaha pengolhan ikan asin di kelurahan sumber jaya kecamatan kampung melayu kota Bengkulu.

4. Biaya tetap adalah biaya yang jumlah nya tetap dan dapat digunakan dalam beberapa kali produksi (Rp/produksi) di

kelurahan sumber jaya kecamatan kampung melayu kota Bengkulu.

5. Biaya variabel adalah biaya yang habis dipakai dalam satu kali produksi (Rp/produksi)

6. Modal adalah setiap hasil atau produk kekayaan yang digunakan untuk memproduksi hasil ikan asin di kelurahan sumber jaya kecamatan kampung melayu kota Bengkulu (Rp).

7. Penerimaan adalah produksi yang dinyatakan dalam bentuk tunai sebelum dikurangi dengan biaya yang dikeluarkan selama kegiatan usaha ( $\mathrm{Rp} /$ produksi).

8. Keuntungan penerimaa bersih yang didapatkan oleh pengusaha pengolahan ikan asin (Rp/produksi)di kelurahan Sumber Jaya kecamatan Kampung Melayu kota Bengkulu.

\section{HASIL DAN PEMBAHASAN}

\section{Karakteristik Pengusaha Ikan Asin} Umur

Umur berperan penting dalam menentukan kedewasaan yang berpengaruh terhadap cara berpikir, dimana umur lebih tua lebih cermat dan lebih berhati-hati dalam proses pengambilan keputusan. Selain itu umur juga sangat berpengaruh terhadap kemampuan fisik dalam melaksanakan sesuatu pekerjaan termasuk mengelola usahatani ikan asin, dimana standar tenaga kerja yang disebut produktif adalah berkisar antara umur $26-58$ tahun. Adapun umur pedagang responden berkisar antara 35 hingga 70 tahun dengan persentase usia produktif sebesar $89.28 \%$.

\section{Pendidikan}


Tingkat pendidikan akan sangat $=139,971 \mathrm{~kg}$

berpengaruh terhadap cara berpikir petani terutama dalam penerapan tehnologi baru dan bertindak dalam pengambilan keputusan sekaligus berpengaruh pula pada peningkatan pendapatan yang pada akhirnya akan meningkatkan kesejahteraan hidup pengusaha ikan asin dan keluarganya. Pendidikan pedagang responden di daerah penelitian terbanyak adalah pendidikan SMA sebanyak $21.42 \%$, tamat SMP sebanyak $39.28 \%$ dan SD sebanyak $39.28 \%$.

\section{Pengalaman Berusaha}

Pengalaman berusaha adalah lamanya berusaha menjadi pengusaha ikan asin. Semakin lama pengalamannya berusaha biasanya akan berpengaruh pada keterampilan dalam suatu usaha. Adapun Lama berusaha berdagang pedagang pengumpul di daerah penelitian antara 510 tahun sebanyak 60,71\%, antara 11-15 tahun sebanyak $32,14 \%$ dan lama berusaha antara 16-20 tahun sebanyak 7,14 $\%$.

\section{Analisis BEP}

Di daerah penelitian ada 3 jenis ikan yang dibuat ikan asin. Adapun BEP masingmasing ikan adalah sebagai berikut :

1. Ikan Kepala Batu

BEP dalam unit

$$
\text { BEP = FC/ (P-VC) }
$$

$=221.294 /(18.000-16.419)$
BEP dalam rupiah

$$
\mathrm{BEP}=\mathrm{FC} /[\mathbf{1}-(\mathrm{VC} / \mathrm{S})]
$$

$=221.294 /(1-2.413 .683 / 2.646 .000)$

$=$ Rp.2.514.704

Jadi untuk ikan kepala batu mempunyai BEP unit sebesar 139,971 kilogram dan BEP dalam rupiah sebesar Rp.2.514.704.

2. Ikan Beledang

BEP dalam unit

$$
\begin{aligned}
& \text { BEP }=\text { FC } /(\mathbf{P}-\text { VC }) \\
& =201.720 /(25.000-17.059) \\
& =25,40 \mathrm{~kg}
\end{aligned}
$$

BEP dalam rupiah

$$
\mathrm{BEP}=\mathrm{FC} /[1-(\mathrm{VC} / \mathrm{S})]
$$

$=201.720 /(1-2.285 .977 / 3.350 .000)$

$=\operatorname{Rp} .634 .339,6$

Jadi untuk ikan beledang mempunyai BEP unit sebesar 25,40 kilogram dan BEP dalam rupiah sebesar Rp.634.339,6

3. Ikan Leberan

BEP dalam unit

$$
\begin{aligned}
& \text { BEP }=\text { FC/ }(\mathbf{P}-\text { VC }) \\
& =192.691 /(25.000-17.059) \\
& =24,882 \mathrm{~kg}
\end{aligned}
$$

BEP dalam rupiah

$$
\mathrm{BEP}=\mathrm{FC} /[\mathbf{1}-(\mathrm{VC} / \mathrm{S})]
$$

$=192.691 /(1-2.208 .8273 .200 .000)$ 
$=\mathrm{Rp} .621 .583,8$

Jadi untuk ikan beledang mempunyai BEP unit sebesar 24,882 kilogram dan BEP dalam rupiah sebesar Rp.621.583,8

Dalam penelitian ini, ketiga jenis ikan yang diusahakan dalam usaha ikan asin sudah melampaui BEP nya artinya usaha ikan asin sudah mengalami keuntungan. Dimana keuntungan yang didapat pengusaha ikan asin ini adalah sebesar Rp. 1.378.797,- per produksi.

\section{Analisis ROI}

Kemampuan pengusaha ikan asin di kelurahan sumber jaya kecamatan kampung melayu kota Bengkulu untuk mengembalikan modal akan mempengaruhi jalannya suatu usaha. Bila kemampuan mengembalikan modal itu persentasenya tinggi, maka menunjukan usaha tersebut efesien. Sebaliknya kemampuan usaha tersebu dalam mengembalikan modal persentasenya rendah maka usah tersebut tidak efesien.

Unutuk mengetahui kemampuan dalam mengembalikan modal dari usaha ikan asin sebagai berikut :

$$
\begin{aligned}
& \text { ROI }=\frac{\text { Laba usaha }}{\text { modal }} x 100 \% \\
& \text { ROI }=\frac{1.378 .797}{61.916 .791} x 100 \% \\
& \text { ROI }=2,21 \%
\end{aligned}
$$

Dengan nilai ROI sebesar $2.21 \%$ ini menggambarkan bahwa dari Rp. 100,00 modal yang digunakan akan diperoleh laba usaha sebesar 2,21. Dengan kata lain tingkat pengembalian modal atau investasi sebesar $2,21 \%$.

\section{KESIMPULAN DAN SARAN}

\section{Kesimpulan}

1. Dalam penelitian ini, ketiga jenis ikan yang diusahakan dalam usaha ikan asin sudah melampaui BEP nya artinya usaha ikan kering sudah mengalami keuntungan. Dimana keuntungan yang didapat pengusaha ikan kering ini adalah sebesar Rp. 1.378.797,-

2. Nilai ROI usaha ikan asin di kelurahan sumber jaya kecamatan kampung melayu kota Bengkulu sebesar $2,21 \%$

\section{Saran}

Dalam pengembangan uasaha ikan asin diperlukan bimbingan dan support dari lembaga pemerintah terkait guna untuk meningkatkan pendapatan dan meningkat kesejahteraan ekonomi masyarakat pengusaha ikan asin di kelurahan sumber jaya kecamtan kampung melayu kota Bengkulu .

\section{DAFTAR PUSTAKA}

Adawyah,R. 2008. Pengolahan Dan Pengawetan Ikan. Bumi aksara. Jakarta: 160 halaman. 
Ade Fitri Y. dkk. 2016. Analisis Kebutuhan Modal Kerja Petani Sawah. Jurnal Agribisnis. Sumatra Utara : Desa Pematang Setrak, Kecamatan Teluk Mengkudu, Kabupaten Serdang Bedagai. Volume 4 (Hlm 10).

Afrianto, E dan Evi Liviawaty. 2017. Pengawetan Dan Pengolahan Ikan. Penerbit Kanislus. Yogyakarta: 125 Halaman.

BPS Kecamtan Kampung Melayu. 2018. Badan Pusat Statistic. Kota Bengkulu (BPS).

BPS Kota Bengkulu. 2018. Bengkulu Municipality In Figures. Badan pusat statistik Kota Bengkulu (BPS).

Ghuforn, M dan Kordi, K. 2011. Marikultur - Prinsip Budi Daya Laut. $\quad$ LILY PUBLISHER Yogyakarta: 618 halaman.

https://www.maxmanroe.com. Pengertian BEP : Rumus BEP, Komponen, Manfaat, dan contoh BEP. (Diunduh 2 september $2019: 14.00$ ).

Muhammad S, 2016. Analisis Break Event Point (BEP) Usaha Ikan Asin. Jurnal Adrimistrasi Bisnis. Kalimantan Timur: Desa Tanjung Agung Kecamatan Tanjung Harapan Kabupaten Paser. Volume 4 (Hlm 142-156).

Mulyadi, 2005. Akuntansi Biaya. Edisi Kelima. Cetakan Ketujuh. UPP AMP YKPN, Yogyakarta.

Mulyadi, S. 2007. Ekonomi Kelautan. PT RajaGrafindo persada. Jakarta: 224 halaman.

Rahardi, dkk. 1999. Agribisnis Perikanan. PT Penebar Swadaya. Bogor.

Reswita, 2014. Kelayakan Usaha Pengolahan Ikan Asin. Jurnal
Agroindustri.Volume 4 (Hlm 16). Bengkulu: Sumber Jaya Kecamatan Kampung Melayu Kota Bengkulu.

Soekartawi, 2006. Analisis Usahatanai. Universitas Indonesia. (UI-press). Jakarta:110 halaman.

Sugiyono. 2014. Statistika Untuk Penelitian. Alfabeta. Bandung: 390 halaman.

Sunyoto, 2013. Analisis Laporan Keuangan Bisnis (Teori Dan Kasus). Alfabeta. Yogyakarta 